\title{
Susceptibility of Spodoptera frugiperda and Chrysodeixis includens (Lepidoptera: Noctuidae) to infections caused by Metarhizium rileyi ${ }^{1}$
}

\author{
Suellen Karina Albertoni Barros², Rafael Major Pitta ${ }^{3}$, \\ Rogério Biaggioni Lopes ${ }^{4}$, Euziclei Gonzaga de Almeida ${ }^{2}$, Fátima Teresinha Rampelotti Ferreira ${ }^{5}$
}

\section{ABSTRACT}

Due to the reduced host spectrum of the entomopathogenic fungus Metarhizium rileyi, its pathogenicity against different target insects must be assessed to develop biopesticides capable of controlling more than one pest species. This study aimed to evaluate the susceptibility of the pest species Chrysodeixis includens and Spodoptera frugiperda to different isolates of $M$. rileyi and, thus, determine a possible influence of the host of origin on the pathogenic activity of these isolates. Three isolates [CG1312 (C. includens as original host), CG381 (S. frugiperda as original host) and a new wild isolate ( $C$. includens as original host)] were tested against larvae of $C$. includens and $S$. frugiperda, in third instar age, by treatment of surfaces with conidial suspension, under laboratory conditions. Both species were susceptible to the isolates of $M$. rileyi, with mortality rates of 53-58 \% for C. includens and 74-84\% for S. frugiperda. The results suggest that the host of origin may not be determinant in the selection of pathogenic isolates of $M$. rileyi against these two pest insects.

KEYWORDS: Biopesticide, soybean looper, fall armyworm, green muscardine, entomopathogenic fungus.

\section{INTRODUCTION}

Chrysodeixis includens (Walker) and Spodoptera frugiperda (JE Smith) (Lepidoptera: Noctuidae) are pest species of great economic importance in grain and fiber crops such as soybean, corn, bean and cotton (Pitre \& Hogg 1983, Bueno et al. 2011, Baldin et al. 2014, Specht et al. 2015).

\section{RESUMO}

Suscetibilidade de Spodoptera frugiperda e

Chrysodeixis includens (Lepidoptera: Noctuidae) a infecções causadas por Metarhizium rileyi

Em razão do reduzido espectro hospedeiro do fungo entomopatogênico Metarhizium rileyi, sua patogenicidade contra diferentes insetos alvos deve ser avaliada para o desenvolvimento de bioinseticidas capazes de controlar mais de uma espéciepraga. Objetivou-se avaliar a suscetibilidade das espécies-pragas Chrysodeixis includens e Spodoptera frugiperda a diferentes isolados de $M$. rileyi e, assim, determinar uma possível influência do hospedeiro de origem na atividade patogênica desses isolados. Três isolados [CG1312 (C. includens como hospedeiro original), CG381 (S. frugiperda como hospedeiro original) e um novo isolado selvagem (C. includens como hospedeiro original)] foram testados contra lagartas de $C$. includens e $S$. frugiperda, em idade de terceiro instar, por tratamento de superfícies com suspensão de conídios, em laboratório. Ambas as espécies foram suscetíveis aos isolados de $M$. rileyi, com índices de mortalidade de 53-58 \% para C. includens e $74-84 \%$ para $S$. frugiperda. Os resultados sugerem que o hospedeiro de origem pode não ser determinante na seleção de isolados patogênicos de $M$. rileyi contra essas duas espécies de praga.

PALAVRAS-CHAVE: Biopesticida, largarta falsa-medideira, lagarta-do-cartucho, muscardine verde, fungo entomopatogênico.

Traditionally, synthetic insecticides and genetically modified plants (Bt-crops) are among the main methods for controlling larval infestations. However, the overuse of chemicals may result in damage to human and environmental health and cause the death of pollinators and natural enemies, in addition to selection of resistant pest populations (Bernardi et al. 2012, Sosa-Gómez \& Omoto 2012, Martins \&

1. Received: Dec. 12, 2019. Accepted: May 05, 2020. Published: July 08, 2020. DOI: 10.1590/1983-40632020v5061713.

2. Universidade Federal de Mato Grosso, Instituto de Biociências, Cuiabá, MT, Brasil.

E-mail/ORCID: albertoni.suellen@hotmail.com/0000-0002-8783-0570, euziclei@yahoo.com.br/0000-0003-1674-6328.

3. Empresa Brasileira de Pesquisa Agropecuária (Embrapa Agrossilvipastoril), Sinop, MT, Brasil. E-mail/ORCID: rafael.pitta@embrapa.br/0000-0002-8503-7106.

4. Empresa Brasileira de Pesquisa Agropecuária (Embrapa Recursos Genéticos e Biotecnologia), Brasília, DF, Brasil. E-mail/ORCID: rogerio.lopes@embrapa.br/0000-0003-4756-878X.

5. Universidade Federal de Mato Grosso, Instituto de Ciências Agrárias e Ambientais, Sinop, MT, Brasil. E-mail/ORCID: ftrampelotti@hotmail.com/0000-0002-3118-9446. 
Tomquelski 2015, Sorgatto et al. 2015, Bernardi et al. 2017, Fernandes et al. 2019). Studies around the world have been carried out to develop alternatives for managing pests in different crops, evidencing the need to advance in the adoption of control methods other than chemical, such as the use of biopesticides based on entomopathogenic fungi (Lacey et al. 2015).

The fungus Metarhizium rileyi (Farlow) Kepler, S. A. Rehner \& Humber (Hypocreales: Clavicipitaceae) (formerly Nomuraea rileyi) has been studied as an alternative in managing lepidopteranpests (Vimala Devi \& Prasad 2000). There are records of 60 lepidopteran species susceptible to this pathogen, of which half are Noctuidae (Fronza et al. 2017). Therefore, M. riley is an entomopathogenic fungus with a great potential to control noctuid pests in several agricultural systems. For instance, $C$. includens and $S$. frugiperda larvae are susceptible to this entomopathogen, and the occurrence of natural epizootics caused by $M$. rileyi on these pest species is often observed in soybean and corn crops, respectively (Pavone et al. 2009, Sosa-Gómez 2017, Souza et al. 2019, Lopes et. al. 2020). Furthermore, the risks posed by this fungus on natural enemies or pollinators are minimal or inexistent, making its use safer, when compared to chemical pesticides (Matter \& Sabbour 2013).

The control of lepidopteran larvae by $M$. rileyi in the field is directly related to its ability to increase in density by dispersing the inoculum from primary foci established in the crop, inducing an epizootic cycle on the host population and becoming a medium to long-term control strategy of caterpillars (Hajek \& St. Leger 1994). On the other hand, natural outbreaks of this fungus are highly dependent on the host species, as well as their density, occurring normally when the pest population has already caused significant damages to the crops (Allen et al. 1971). Thus, the inoculum increment by field applications of the fungus may be determinant for effectively controlling lepidopteran pests.

An important step to develop new biopesticides based on $M$. rileyi is to select virulent strains to different caterpillar species (Souza et al. 2019). Fungal strains capable of infecting a certain species may or may not cause high mortality rates in other species, since there is a host specificity of naturally occurring strains (Tigano-Milani et al. 1995, Srisukchayakul et al. 2005). Genetic variations inherent to each fungal strain provide them with varied characteristics related to pathogenicity and virulence, directly influencing host-pathogen interactions (Bianco \& Perrota 2015). Therefore, in the present study, laboratory experiments were carried out to evaluate the susceptibility of $C$. includens and $S$. frugiperda to $M$. rileyi isolates and, thus, to determine some influence of the original host on the biological activity of these isolates.

\section{MATERIAL AND METHODS}

The experiments were carried out at the Embrapa Agrossilvipastoril (Sinop, Mato Grosso state, Brazil), in 2019. S. frugiperda and C. includens colonies were kept in the laboratory for successive generations at $26 \pm 1{ }^{\circ} \mathrm{C}$, relative humidity $(\mathrm{RH})$ of $60 \pm 10 \%$ and photophase of 14 hours. The adult insects were kept inside cages made with polyvinyl chloride (PVC) tubes, coated with A4 paper for oviposition and covered with voile fabric. For adult feeding, $10 \%$ sucrose aqueous solutions were provided and, every two days, the papers presenting eggs were removed from the cages and placed in a Gerbox containing an artificial diet (adapted from Greene et al. 1976). Next, the caterpillars were individualized in test tubes containing an artificial diet for a new breeding cycle or were used in bioassays.

Three $M$. rileyi isolates were selected for this study: CG381 (originally obtained from infected S. frugiperda caterpillars, in Planaltina, DF, Brazil) and CG1312 (originally obtained from infected C. includens caterpillars, in Buritis, Minas Gerais state, Brazil), both from the invertebrate-associated fungal collection of the Embrapa Recursos Genéticos e Biotecnologia; and a wild isolate named Native, collected from C. includens cadavers in Sinop (Mato Grosso state, Brazil). The request for access to the genetic heritage for the isolates above mentioned was registered with the SisGen certificate code AF5D9B3.

For both the caterpillar species, bioassays were conducted in a completely randomized design, with three isolates + control treatment (water), in 10 replicates, with each isolate being composed of 100 third-instar larvae, divided into repetitions of 10 individuals each. The isolates were initially inoculated with conidial suspension (c.a. $2 \times 10^{7}$ conidia $\mathrm{mL}^{-1}$ ) on third-instar caterpillars from their original hosts and reisolated on sabouraud maltose agar + yeast extract (SMAY) culture medium, from the mummified cadavers, before the bioassays. 
Next, the isolates were incubated for 9 to 12 days at $25^{\circ} \mathrm{C} \pm 2{ }^{\circ} \mathrm{C}, 70 \% \pm 10 \% \mathrm{RH}$ and 12 -h photophase. After this period, the conidia on the culture media were collected using a stainless steel spatula and stored at $-20^{\circ} \mathrm{C}$, until the bioassays were carried out.

Before performing the bioassays, the viability of the conidia of each isolate was verified (adapted from Neves et al. 2001). Briefly, M. rileyi conidia were suspended in water + Tween $80^{\mathrm{TM}}(0.1 \%)$ and then $0.1 \mathrm{~mL}$ of the conidial suspension was spread using a Drigalski loop in four Petri dishes containing SMAY culture medium. The plates were incubated at $25^{\circ} \mathrm{C} \pm 2{ }^{\circ} \mathrm{C}, 70 \% \pm 10 \% \mathrm{RH}$ and 12 -h photophase and, after 48 hours, the percentage of germinated conidia in five fields per Petri dish was quantified with an optical microscope (400x of magnification). Only samples with conidial viability above $80 \%$ were used in the bioassays. The conidial concentrations for the bioassays were determined using a Neubauer ${ }^{\mathrm{TM}}$ chamber.

The contaminated surface method was used to perform the bioassays, in which suspensions of each isolate were prepared in sterile water + Tween $80^{\mathrm{TM}}(0.1 \%)$, at the concentration of $2 \times 10^{9}$ viable conidia $\mathrm{mL}^{-1}$. The suspensions $(800 \mu \mathrm{l})$ of each isolate were sprayed on Petri dishes $(15 \mathrm{~cm}$ in diameter) using 2-mL glass flasks with a spray valve, making sure that the entire surface of the plates was covered with the cell suspension. Only sterile distilled water + Tween $80^{\mathrm{TM}}(0.1 \%)$ were sprayed on the plates in the control treatment. The insects were transferred to the treated plate after the water evaporation and, after one hour in the plates, the larvae were individualized in glass tubes containing $5 \mathrm{~mL}$ of an artificial diet and kept in an acclimatized chamber at $25^{\circ} \mathrm{C} \pm 2{ }^{\circ} \mathrm{C}, 70 \% \pm 10 \% \mathrm{RH}$ and 12 -h photophase. The larval mortality was evaluated daily up to the pupae formation. Individuals were considered killed by the fungus when typical signs of infection, such as mummified body, followed by mycelium growth and formation of greenish conidia, were seen.

The normality and homoscedasticity of mortality data were assessed by the Shapiro-Wilk and Bartlett tests. As the data set was well-modeled by normality and homoscedasticity precepts, the analysis of variance was applied and the means were compared by the Tukey test at $5 \%$ of probability. The Kaplan-Meier survival analysis was performed in pairwise comparisons by the log-rank test (Mantel-Cox) to verify the differences between survival curves. The R 3.6.1 free software was chosen for these analyzes, and the "survival" package of this software was used to carry out the survival analyzes (R Development Core Team 2019). LT $_{50}$ (mean lethal time) was calculated using the PoloPlus 0.03 software (LeOra Software 2003).

\section{RESULTS AND DISCUSSION}

The larval mortality rates caused by the isolates at the end of the experimental period did not differ significantly for the C. includens $\left(\mathrm{F}_{2,27}=\right.$ $0.23 ; \mathrm{p}=0.79)$ and $S$. frugiperda $\left(\mathrm{F}_{2,27}=2.3367\right.$; $\mathrm{p}=0.11)$ caterpillars. For $C$. includens, the larval mortality was $55.0 \% \pm 2.68$ for the CG1312 isolate, $53.0 \% \pm 5.78$ for CG381 and $58.0 \% \pm 6.46$ for Native. For S. frugiperda, these same isolates caused larval mortality rates of $77.5 \% \pm 2.80,84.0 \% \pm 3.39$ and $74.5 \% \pm 3.20$, respectively. No mortality was observed in the control treatments (Figure 1).

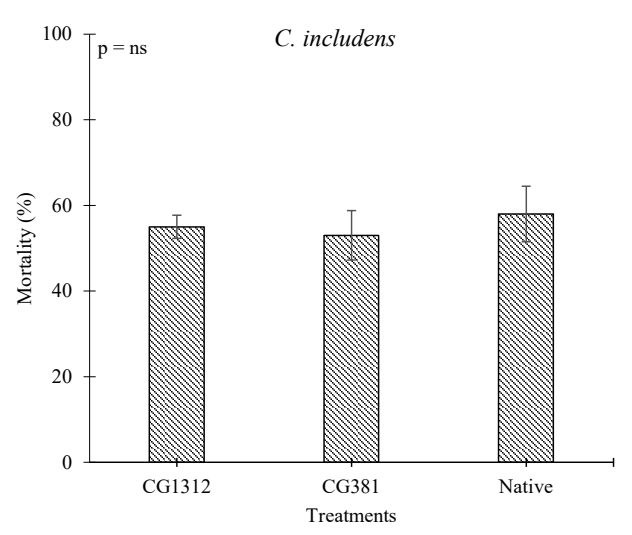

(a)

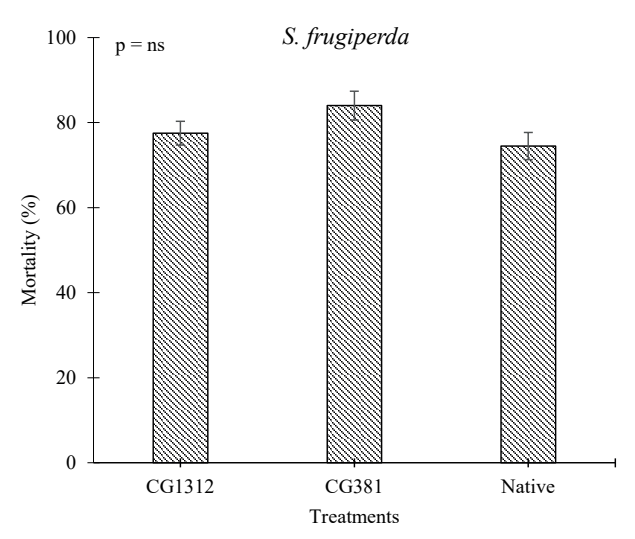

Figure 1. Mortality rates (mean \pm standard error) of Chrysodeixis includens and Spodoptera frugiperda caterpillars caused by Metarhizium rileyi isolates after surface treatment at a concentration of 2 x $10^{9}$ viable conidia $\mathrm{mL}^{-1}$. ns: non-significant mean differences at $5 \%$ of probability by the Tukey test. 
It was observed, therefore, that the original hosts of the isolates did not influence the fungal activity on the different target insects, when they were exposed to high concentrations of conidia. The ability of the $M$. rileyi fungus to cause epizootics in caterpillar populations in the field (Ignoffo 1981, Sujii et al. 2002) and the increased incidence of the disease in commercial crops after releasing propagules of the fungus (Ignoffo et al. 1976a) indicate its great potential to control lepidopterans. The use of isolates with a larger host spectrum opens a new perspective for the future development of biopesticides against infestations of multiple species of caterpillars in different crops. In the present study, it was possible to identify $M$. rileyi isolates with a high activity on the two important caterpillar pests in grain crops.
The survival analyzes also indicated that there was no difference among the treatments for caterpillars of $C$. includens $\left(\chi^{2}=1.9 ; \mathrm{df}=2 ; \mathrm{p}=0.4\right)$ and $S$. frugiperda $\left(\chi^{2}=5 ; \mathrm{df}=2 ; \mathrm{p}=0.08\right)$ (Figure 2$)$. The larval survival started to decrease on the fifth day after the larval exposure, and this reduction was more prominent between the sixth and eighth day of evaluation.

The estimated average lethal times $\left(\mathrm{LT}_{50}\right)$ for the $C$. includens caterpillars were 7.5, 8.2 and 7.3 days, when respectively exposed to the isolates CG1312, CG381 and Native (Table 1). In the bioassays performed with $S$. frugiperda larvae, the estimated $\mathrm{LT}_{50}$ were 5.6, 5.9 and 5.7 days, respectively for CG1312, CG381 and Native (Table 1).

Previous studies have shown a variation in the susceptibility of lepidopterans to infections caused by

Table 1. Lethal time $\left(\mathrm{LT}_{50}\right)$ for Chrysodeixis includens and Spodoptera frugiperda larvae treated with CG1312, CG381 and Native Metarhizium rileyi isolates.

\begin{tabular}{|c|c|c|c|c|c|}
\hline Treatments & $\mathrm{LT}_{50}$ (days) & $95 \%$ confidence interval (days) & Equation $^{(a)}$ & $\mathrm{Df}^{(\mathrm{b})}$ & $\chi^{2}$ \\
\hline \multicolumn{6}{|c|}{ C. includens } \\
\hline CG1312 & 7.5 & $7.13-8.19$ & $Y=-2.425+8.456 \log X$ & 6 & $7.7 *$ \\
\hline CG381 & 8.2 & $7.73-9.04$ & $Y=-2.383+8.056 \log X$ & 7 & $14.2 *$ \\
\hline Native & 7.3 & $7.02-7.61$ & $\mathrm{Y}=-2.814+9.059 \log \mathrm{X}$ & 6 & $4.8^{*}$ \\
\hline \multicolumn{6}{|c|}{ S. frugiperda } \\
\hline CG1312 & 5.6 & $5.05-6.03$ & $Y=0.521+5.987 \log X$ & 4 & $4.4^{*}$ \\
\hline CG381 & 5.9 & $5.30-6.49$ & $Y=0.070+6.341 \log X$ & 4 & $6.7 *$ \\
\hline Native & 5.7 & $5.08-6.19$ & $Y=-1.469+8.524 \log X$ & 4 & $8.8^{*}$ \\
\hline
\end{tabular}

${ }^{\text {(a) }}$ Equations obtained by probit analysis, where $\mathrm{Y}$ is the probit value and $\mathrm{X}$ the conidia concentration. ${ }^{\text {(b) }}$ Df: degree of freedom. * Significant values by the Chi-square $\left(\chi^{2}\right)$ test at $5 \%$ of probability.
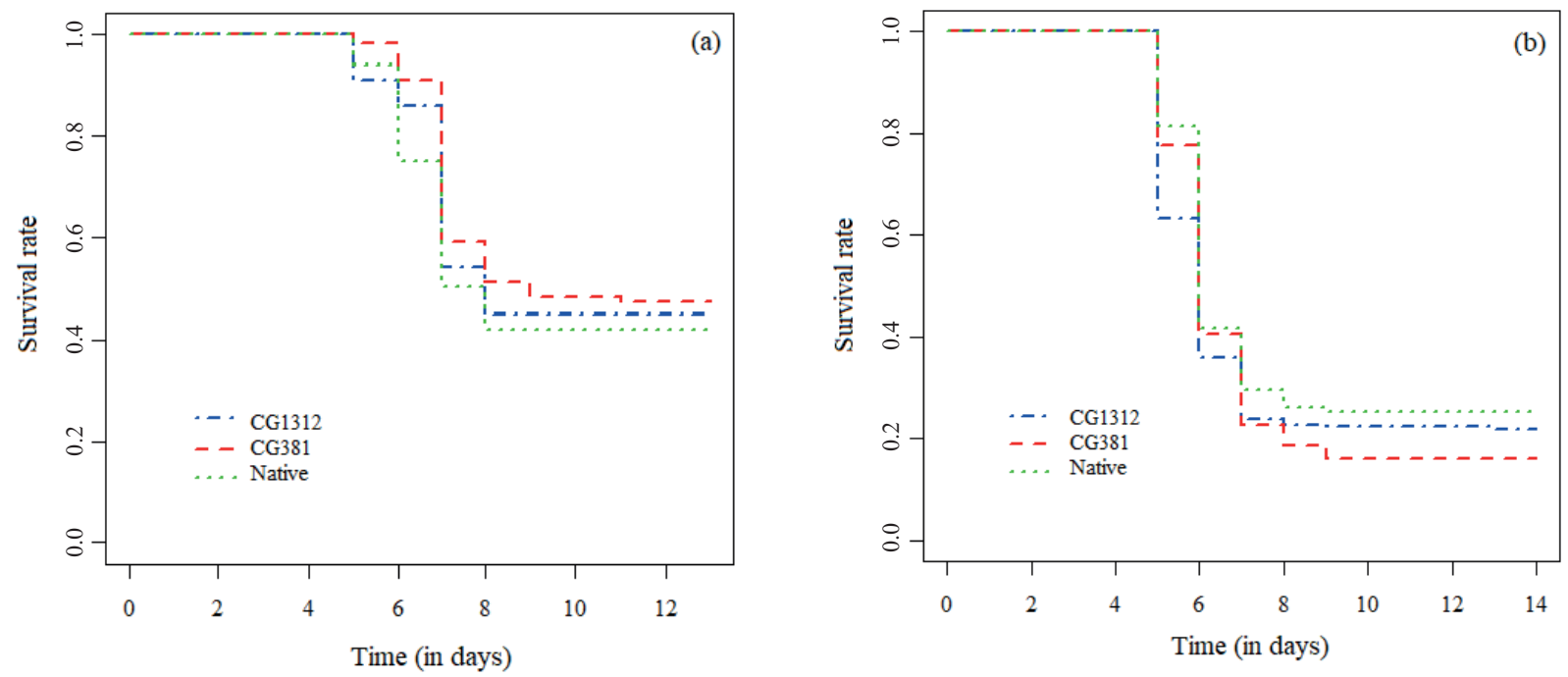

Figure 2. Survival rates of Chrysodeixis includens (a) and Spodoptera frugiperda (b) larvae after exposure to different isolates of Metarhizium rileyi (CG1312, CG381 and Native). 
the $M$. rileyi fungus (Ignoffo et al. 1976b, Puttler et al. 1976, Ignoffo \& Garcia 1987, Kulkarni \& Lingappa 2002). The successful infection and evolution of the disease caused by $M$. rileyi in larvae have a direct relation with the specificity of the different fungal isolates, as well as the tolerance of the host species (Fronza et al. 2017). The absence of certain attributes of the isolate related to the penetration mechanisms and/or characteristics of the host integument may influence the germination success and host invasion by the pathogen (Ignoffo \& Garcia 1985). Although $M$. rileyi isolates may show high specificity to some caterpillars, causing high mortality rates in less tolerant hosts, such variation in susceptibility can be considered to improve the screening studies of strains with a broader host spectrum (Boucias et al. 1982). For example, candidates for the control of defoliating caterpillars in soybean could be selected based on their activity only against $C$. includens, since $S$. frugiperda seemed to be more susceptible to the fungus, according to our bioassays.

The host and geographic origin of $M$. rileyi isolates to a specific target have also been the objective of specificity studies. Ignoffo \& Boucias (1992) suggest that the homogeneity of the fungus isolates in their ability to infect larvae of some lepidopterans is more dictated by the host than the geographic origin. According to Boucias et al. (2000), M. rileyi isolates show a greater virulence to the host species from which they were isolated. However, this effect was not evidenced in our study, since the final mortality of the individuals was similar for the three isolates evaluated in the two hosts, although the $\mathrm{LT}_{50}$ values of $C$. includens exposed to the CG1312 and Native isolates (C. includens as original host) were lower than for the CG381 isolate (S. frugiperda as original host). This trend was not repeated for the $\mathrm{LT}_{50}$ of $S$. frugiperda, as the three isolates did not differ.

Other factors, such as the amount of inoculum and the larvae age, may influence the virulence of the tested isolate. A study by Patil et al. (2014) demonstrated that the $\mathrm{LT}_{50}$ of $M$. rileyi isolates for some Lepidoptera species, when tested in the 4th and 5 th instars, were superior to those observed in the present study for earlier developmental instar, indicating the importance of standardizing studies on host susceptibility and isolate screening. The germination period of conidia and the complete development cycle of $M$. rileyi in the host generally occur up to 6-8 days, varying according to the isolates, inoculum concentration and host species involved (Srisukchayakul et al. 2005).

The interest of growers in the use of biopesticides has increased worldwide in recent decades, due to the increased cost of developing new safer chemical compounds (Glare et al. 2012) and a concern with the evolution of resistance to chemical insecticides and pest resurgence (Dutcher 2007). The soybean and corn production has been limited, among other factors, by the attack of lepidopteran pests, and the use of $M$. rileyi may contribute to the management of these insects, in order to reduce the environmental and economic impacts provoked by the intensive use of synthetic insecticides. In general, the isolates evaluated in the present study have the potential to be used as biopesticides to simultaneously control $C$. includens and $S$. frugiperda larvae, in soybean and corn crops. Fronza et al. (2017) point out the difficulty of mass production and formulation as technological bottlenecks to use some entomopathogenic fungi. Given this, complementary studies on the formulation, large-scale production and efficiency of these isolates against these pest species under field conditions are necessary to develop a future biopesticide based on $M$. rileyi.

\section{CONCLUSIONS}

The pest insects Chrysodeixis includens and Spodoptera frugiperda showed to be susceptible to isolates of Metarhizium rileyi (e.g., CG1312 and CG381, respectively isolated from C. includens and $S$. frugiperda caterpillars; and another native wild from $C$. includens cadavers). Our results suggest that the host of origin may not be determinant in the selection of pathogenic isolates of $M$. rileyi against these pest insects.

\section{ACKNOWLEDGMENTS}

The authors thank the Fundo de Apoio à Cultura da Soja (FACS) and Associação dos Produtores de Soja e Milho do Estado de Mato Grosso (Aprosoja/MT), for granting scholarships to the first author.

\section{REFERENCES}

ALLEN, G. E.; GREENE, G. L.; WHITCOMB, W. H. An epizootic of Spicaria rileyi on the velvetbean caterpillar, 
Anticarsia gemmatalis, in Florida. Florida Entomologist, v. 54, n. 2, p. 189-191, 1971.

BALDIN, E. L. L.; LOURENÇÃO A. L.; SCHLICKSOUZA, E. C. Outbreaks of Chrysodeixis includens (Walker) (Lepidoptera: Noctuidae) in common bean and castor bean in São Paulo State, Brazil. Bragantia, v. 73, n. 4, p. 458-465, 2014.

BERNARDI, D.; BERNARDI, O.; HORIKOSHI, R. J.; SALMERON, E. Selection and characterization of Spodoptera frugiperda (Lepidoptera: Noctuidae) resistance to MON 89034 x TC1507 x NK603 maize technology. Crop Protection, v. 94, n. 4, p. 64-68, 2017.

BERNARDI, O.; MALVESTITI, G. S.; DOURADO, P. M.; OLIVEIRA, W. S.; MARTINELLI, S.; BERGER, G. U.; HEAD, G. P.; OMOTO, C. Assessment of the high dose concept and level of control provided by MON $87701 \times$ MON 89788 soybean against Anticarsia gemmatalis and Pseudoplusia includens (Lepidoptera: Noctuidae) in Brazil. Pest Management Science, v. 68, n. 7, p. 10831091, 2012.

BIANCO, L.; PERROTA, G. Methodologies and perspectives of proteomics applied to filamentous fungi: from sample preparation to secretoma analisys. International Journal of Molecular Sciences, v. 16, n. 3 , p. 5803-5820, 2015.

BOUCIAS, D. G.; SCHOBORG, E. A.; ALLEN, G. E. The relative susceptibility of six noctuid species to infection by Nomuraea rileyi isolated from Anticarsa gemmatalis. Journal of Invertebrate Pathology, v. 39, n. 2, p. 238-240, 1982.

BOUCIAS, D. G.; TIGANO, M. S.; SOSA-GOMEZ, D. R.; GLARE, T. R.; INGLIS, P. W. Genotypic properties of the entomopathogenic fungus Nomuraea rileyi. Biological Control, v. 19, n. 2, p. 124-138, 2000.

BUENO, R. C. O. F.; BUENO, A. F.; MOSCARDI, F.; PARRA, J. R.; HOFFMANN-CAMPO, C. B. Lepidopteran larvae consumption of soybean foliage: basis for developing multiple-species economic thresholds for pest management decisions. Pest Management Science, v. 67, n. 2, p. 170-174, 2011.

DUTCHER, J. D. A review of resurgence and replacement causing pest outbreaks in IPM. In: CIANCIO, A.; MUKERJI, Q. G. (ed.). General concepts in integrated pest and disease management. Dordrecht: Springer, 2007. p. 27-43.

FERNANDES, F. O.; ABREU, J. A.; CHRIST, L. M.; ROSA, A. P. S. A. Efficacy of insecticides against Spodoptera frugiperda (Smith, 1797). Journal of Agricultural Science, v. 11, n. 1, p. 494-503, 2019.

FRONZA, E.; SPECHT, A.; HEINZEN, H.; BARROS, N. M. Metarhizium (Nomuraea) rileyi as biological control agent. Biocontrol Science and Technology, v. 27, n. 11, p. 1243-1264, 2017.

GLARE, T.; CARADUS, J.; GELERNTER, G.; JACKSON, J.; KEYHANI, N.; KOHL, J.; MARRONE, P.; MORIN, L.; STEWART, A. Have biopesticides come of age? Trends in Biotechnology, v. 30, n. 5, p. 250-258, 2012.

GREENE, G. L.; LEPPLA, N. C.; DICKERSON, W. A. Velvetbean caterpillar: a rearing procedure and artificial medium. Journal of Economic Entomology, v. 69, n. 4, p. 487-488, 1976.

HAJEK, A. E.; ST. LEGER, R. J. Interactions between fungal pathogens and insect host. Annual Review of Entomology, v. 39, n. 1, p. 293-322, 1994.

IGNOFFO, C. M.; BOUCIAS, D. B. Relative activity of geographical isolates of Nomuraea bioassayed against the cabbage looper and velvetbean caterpillar. Journal of Invertebrate Pathology, v. 59, n. 2, p. 215-217, 1992.

IGNOFFO, C. M.; GARCIA, C. Host spectrum and relative virulence of an Ecuadoran and a Mississippian biotype of Nomuraea rileyi. Journal of Invertebrate Pathology, v. 45, n. 3, p. 346-352, 1985.

IGNOFFO, C. M.; GARCIA, C. Susceptibility of six species of noctuid larvae to a biotype of Nomuraea rileyi (Farlow) Samson from Thailand (Lepidoptera: Noctuidae). Journal of the Kansas Entomological Society, v. 60, n. 1, p. 156-158, 1987.

IGNOFFO, C. M.; MARSTON, N. L.; HOSTETTER, D. L.; PUTTLER, B.; BELL, J. V. Natural and induced epizootics of Nomuraea rileyi in soybean caterpillars. Journal of Invertebrate Pathology, v. 27, n. 2, p. 191198, 1976a.

IGNOFFO, C. M.; PUTTLER, B.; HOSTETTER, D. L.; DICKERSON, W. A. Susceptibility of the cabbage looper, Trichoplusia ni, and the velvetbean caterpillar, Anticarsia gemmatalis, to several isolates of the entomopathogenic fungus Nomuraea rileyi. Journal of Invertebrate Pathology, v. 28, n. 2, p. 259-262, 1976 b.

IGNOFFO, C. The fungus Nomuraea rileyi as a microbial insecticide. In: BURGES, H. D. (ed.). Microbial control of pests and plant diseases 1970-1980. London: Academic Press, 1981. p. 513-538.

KULKARNI, N. S.; LINGAPPA, S. Pathogenicity of entomopathogenic fungus, Nomuraea rileyi (Farlow) Samson on lepidopterous pest. Karnataka Journal of Agricultural Science, v. 15, n. 2, p. 293-298, 2002.

LACEY, L. A.; GRZYWACZ, D.; SHAPIRO-ILAN, D. I.; FRUTOS, R.; BROWNBRIDGE, M.; GOETTEL, M. $\mathrm{S}$. Insect pathogens as biological control agents: back to the future. Journal of Invertebrate Pathology, v. 132, n. 1, p. 1-41, 2015. 
LEORA SOFTWARE. Poloplus: a user's guide to probit or logit analysis. Berkeley: LeOra Software, 2003.

LOPES, R. B.; SOSA-GÓMEZ, D. R.; OLIVEIRA, C. M.; SANCHES, M. M.; SOUZA, D. A.; BENITO, N. P.; FARIA, M. Efficacy of an oil-based formulation combining Metarhizium rileyi and nucleopolyhedroviruses against lepidopteran pests of soybean. Journal of Applied Entomology, v. 144, n. 5, p. 1-12, 2020.

MARTINS, G. L. M.; TOMQUELSKI, G. V. Efficiency of insecticides on Chrysodeixis includens (Lepidoptera: Noctuidae) on soybean crop. Revista de Agricultura Neotropical, v. 2, n. 4, p. 25-30, 2015.

MATTER, M. M.; SABBOUR, M. M. Differential efficacies of Nomuraea rileyi and Isaria fumosorosea on some serious pests and the pests' efficient predator prevailing in tomato fields in Egypt. Journal of Plant Protection Research, v. 53, n. 2, p. 103-109, 2013.

NEVES, P. M. O. J.; HIROSE, E.; TCHUJO, P. T.; MOINO JUNIOR, A. Compatibility of entomopathogenic fungi with neonicotinoids inseticides. Neotropical Entomology, v. 30, n. 2, p. 263-268, 2001.

PATIL, R. K.; BHAGAT, Y. S.; HALAPPA, B.; BHAT, R. S. Evaluation of entomopathogenic fungus, Nomuraea rileyi (Farlow) Samson for the control of groundnut Spodoptera litura (F.) and its compatibility with synthetic and botanical pesticides. Jounal of Biopesticides, v. 7 (suppl.), p. 106-115, 2014.

PAVONE, D.; DÍAZ, M.; TRUJILLO, L.; DORTA, B. A granular formulation of Nomuraea rileyi Farlow (Samson) for the control of Spodoptera frugiperda (Lepidoptera: Noctuidae). Interciência, v. 34, n. 2, p. 130-134, 2009.

PITRE, H. N.; HOGG, D. B. Development of the fall armyworm on cotton, soybean and corn. Journal of the Georgia Entomological Society, v. 18, n. 2, p. 182-187, 1983.

PUTTleR, B.; IGNOFFO, C. M.; HOSTETTER, D. L. Relative susceptibility of nine caterpillar species to the fungus Nomureae rileyi. Journal of Invertebrate Pathology, v. 27, n. 2, p. 269-270, 1976.

R DEVELOPMENT CORE TEAM. $R$ : a language and environment for statistical computing. Vienna: $R$ Foundation for Statistical Computing, 2019.

SORGATTO, R. J.; BERNARDI, O.; OMOTO, C. Survival and development of Spodoptera frugiperda and Chrysodeixis includens (Lepidoptera: Noctuidae) on Bt cotton and implications for resistance management strategies in Brazil. Environmental Entomology, v. 44, n. 1, p. 186-192, 2015.

SOSA-GÓMEZ, D. R. Microbial control of soybean pest insects and mites. In: LACEY, L. A (ed.). Microbial control of insect and mite pests: from theory to practice. Cambridge: Academic Press, 2017. p. 199-208.

SOSA-GÓMEZ, D. R.; OMOTO, C. Resistência a inseticidas e outros agentes de controle em artrópodes associados à cultura da soja. In: HOFFMANN-CAMPO, C. B.; CORRÊA-FERREIRA, B. S.; MOSCARDI, F. Soja: manejo integrado de insetos e outros artrópodes-praga. Brasília, DF: Embrapa, 2012. p. 673-723.

SOUZA, M. L.; SANCHES, M. M.; SOUZA, D. A. da; FARIA, M.; ESPINEL-CORREAL, C.; SIHLER, W.; LOPES, R. B. Within-host interactions of Metarhizium rileyi strains and nucleopolyhedroviruses in Spodoptera frugiperda and Anticarsia gemmatalis (Lepidoptera: Noctuidae). Journal of Invertebrate Pathology, v. 162, n. 1, p. 10-18, 2019.

SPECHT, A.; PAULA-MORAES, S. V. de; SOSAGÓMEZ, D. R. Host plants of Chrysodeixis includens (Walker) (Lepidoptera, Noctuidae, Plusiinae). Revista Brasileira de Entomologia, v. 59, n. 4, p. 343-345, 2015.

SRISUKCHAYAKUL, P.; WIWAT, C.; PANTUWATANA, S. Studies on the pathogenesis of the local isolates of Nomuraea rileyi against Spodoptera litura. Sciencia Asia, v. 31, n. 1, p. 273-276, 2005.

SUJII, E. R.; TIGANO, M. S.; SOSA-GÓMEZ, D. Simulação do impacto do fungo Nomuraea rileyi em populações da lagarta da soja, Anticarsia gemmatalis. Pesquisa Agropecuária Brasileira, v. 37, n. 11, p. 15511558, 2002.

TIGANO-MILANI, M. S.; FARIA, M. R.; LECUONA, R. E.; SARTORI, M. R.; ARIMA, E. Y.; DIAZ, B. M. Análise de patogenicidade e germinação do fungo Nomuraea rileyi (Farlow) Samson isolado no Distrito Federal. Anais da Sociedade Entomológica do Brasil, v. 24, n. 1, p. 53-60, 1995.

VIMALA DEVI, P. S.; PRASAD, Y. G. Nomuraea rileyi: a potential mycoinsecticide. In: UPADHYAY, R. K.; MUKHERJI, K. G.; CHAMOLA, B. P. (ed.). Biocontrol potential and its exploitation in sustainable agriculture v. 2: insect pests. New York: Kluwer Academic, 2000. p. 23-38. 